\title{
Liver-specific disruption of PPAR $\gamma$ in leptin-deficient mice improves fatty liver but aggravates diabetic phenotypes
}

\author{
Kimihiko Matsusue, ${ }^{1}$ Martin Haluzik, ${ }^{2}$ Gilles Lambert, ${ }^{3}$ Sun-Hee Yim, ${ }^{1}$ \\ Oksana Gavrilova, ${ }^{2}$ Jerrold M. Ward, ${ }^{4}$ Bryan Brewer, Jr., ${ }^{3}$ Marc L. Reitman, ${ }^{2}$ \\ and Frank J. Gonzalez ${ }^{1}$ \\ ${ }^{1}$ Laboratory of Metabolism, National Cancer Institute, \\ ${ }^{2}$ Diabetes Branch, National Institute of Diabetes and Digestive and Kidney Diseases, \\ ${ }^{3}$ Molecular Disease Branch, National Heart, Lung, and Blood Institute, and \\ ${ }^{4}$ Veterinary and Tumor Pathology Section, Center for Cancer Research, National Cancer Institute, National Institutes of \\ Health, Frederick, Maryland, USA
}

To elucidate the function of PPAR $\gamma$ in leptin-deficient mouse $(o b / o b)$ liver, a PPAR $\gamma$ liver-null mouse on an $o b / o b$ background, $o b / o b$-PPAR $\gamma(f l / f l) \mathrm{AlbCre}^{+}$, was produced using a floxed PPAR $\gamma$ allele, $\operatorname{PPAR} \gamma(f l / f l)$, and Cre recombinase under control of the albumin promoter (AlbCre). The liver of $o b / o b$-PPAR $\gamma(f l / f l)$ AlbCre ${ }^{+}$mice had a deletion of exon 2 and a corresponding loss of full-length PPAR $\gamma$ mRNA and protein. The PPAR $\gamma$-deficient liver in $o b / o b$ mice was smaller and had a dramatically decreased triglyceride (TG) content compared with equivalent mice lacking the AlbCre transgene $\left(o b / o b\right.$-PPAR $\left.\gamma(f l / f l) A l b C r e^{-}\right)$. Messenger RNA levels of the hepatic lipogenic genes, fatty acid synthase, acetyl-CoA carboxylase, and stearoyl-CoA desaturase- 1 , were reduced in $o b / o b$-PPAR $\gamma(f l / f l) \mathrm{AlbCre}^{+}$ mice, and the levels of serum TG and FFA in $o b / o b-\mathrm{PPAR} \gamma(f l / f l) \mathrm{AlbCre}^{+}$mice were significantly higher than in the control $o b / o b$-PPAR $\gamma(f l / f l) \mathrm{AlbCre}^{-}$mice. Rosiglitazone treatment exacerbated the fatty liver in $o b / o b$-PPAR $\gamma(f l / f l) \mathrm{AlbCre}^{-}$mice compared with livers from nonobese $\mathrm{Cre}^{-}$mice; there was no effect of rosiglitazone in $o b / o b$-PPAR $\gamma(f l / f l) \mathrm{AlbCre}^{+}$mice. The deficiency of hepatic PPAR $\gamma$ further aggravated the severity of diabetes in $o b / o b$ mice due to decreased insulin sensitivity in muscle and fat. These data indicate that hepatic PPAR $\gamma$ plays a critical role in the regulation of TG content and in the homeostasis of blood glucose and insulin resistance in steatotic diabetic mice.

J. Clin. Invest. 111:737-747 (2003). doi:10.1172/JCI200317223.

\section{Introduction}

PPAR $\gamma$ is a nuclear receptor that heterodimerizes with retinoid $X$ receptor $\alpha$ and activates genes involved in lipid storage and metabolism. It is required for lipid homeostasis $(1,2)$. Immortalized fibroblasts lacking PPAR $\gamma$ lose the potential for differentiation to mature adipocytes (3), indicating that PPAR $\gamma$ is absolutely required for differentiation of preadipocytes to mature adipocytes. PPAR $\gamma$ also plays a critical role in

Received for publication October 19, 2002, and accepted in revised form January 7, 2003

Address correspondence to: Frank J. Gonzalez, Building 37, Room 2A19, National Institutes of Health, Bethesda, Maryland 20892, USA. Phone: (301) 496-9067; Fax: (301) 496-8419; E-mail: fjgonz@helix.nih.gov.

Martin Haluzik's present address is: Department of Medicine, Faculty of Medicine, Charles University, Prague, Czech Republic. Gilles Lambert's present address is: INSERM U539, Nantes, France.

Marc L. Reitman's present address is: Merck Research Laboratories, Rahway, New Jersey, USA.

Conflict of interest: The authors have declared that no conflict of interest exists.

Nonstandard abbreviations used: Cre recombinase under control of the albumin promoter (AlbCre); malic enzyme (MAL); ATPcitrate lyase (ACL); glycerol-3-phosphate acyltransferase (GPAT); triglyceride (TG); fatty acid synthase (FAS); acetyl-CoA carboxylase (ACC); stearoyl-CoA desaturase-1 (SCD1); liver X receptor (LXR); peroxisome proliferator response element (PPRE). the regulation of cholesterol homeostasis in the macrophage $(4,5)$. PPAR $\gamma^{\prime-}$ embryos die at embryonic day 9.5-10 due to placental dysfunction (6). Therefore, determination of the physiological function of PPAR $\gamma$ in mice has been limited to the study of heterozygous PPAR $\gamma^{\dagger-}$ animals $(7,8)$.

PPAR $\gamma$ is expressed at the highest level in adipose tissue $(9,10)$, colon epithelium (11-13), and macrophages $(14,15)$. In contrast to these tissues or cells, the expression of PPAR $\gamma$ in liver is very low $(10,15,16)$. PPAR $\gamma$ is normally expressed in both human and murine liver at only $10-30 \%$ of the level in adipose tissue $(10,15,16)$. The function of PPAR $\gamma$ in liver is not clear. However, it is noteworthy that PPAR $\gamma$ is expressed at elevated levels in the liver of a number of murine models of diabetes or obesity, including $a P 2 / D T A$ (17), A-ZIP/F1 (18), $o b / o b(19,20), d b / d b(19), K K A(21)$, and 5-HT2cR (19) mutant mice. Levels of hepatic PPAR $\gamma$ were elevated by seven- to ninefold in $o b / o b$ and $d b / d b$ mice compared with wild-type mice. The elevation in expression of the $U C P 2$ and $C D 36$ genes, known target genes of PPAR $\gamma$, suggests that PPAR $\gamma$ in $o b / o b$ liver is functional (19). However, the physiological role of hepatic PPAR $\gamma$ remains to be clarified.

To determine the role of hepatic PPAR $\gamma$ in a diabetic mouse model and to circumvent the embryonic lethality of a standard gene knockout model, conditional- 
null mice were created using the Cre-loxP strategy and a $C r e$ transgene derived from the interferon $\alpha / \beta$ promoter (MxCre) (4). The resultant PPAR $\gamma(f l / f l) M x C r e$ mice lacked expression of PPAR $\gamma$ in liver, but also in other tissues, including spleen and kidney. To produce a liver-specific PPAR $\gamma$-null mouse model, a liver-specific albumin promoter-driven Cre transgene, AlbCre, was used to generate PPAR $\gamma(f l / f l)$ AlbCre mice. These mice were bred with $o b / o b$ mice to obtain liver-specific disruption of PPAR $\gamma$ in $o b / o b$ mice. Here we show that $o b / o b$ mice with a liver-specific disruption of PPAR $\gamma$ exhibited a dramatic improvement in fatty liver but had exacerbated hyperglycemia and insulin resistance.

\section{Methods}

Generation of liver-specific PPAR $\gamma$ conditional-null mice. $\operatorname{PPAR} \gamma(f l / f l)$ mice, produced as described (4), were bred with a mouse containing the AlbCre transgene (22), kindly provided by Derek LeRoith of the National Institute of Diabetes and Digestive and Kidney Diseases, NIH. This transgene was used in an earlier study to create an HNF $4 \alpha$ liver-null mouse (23). Heterozygous $(f l /+)$ animals carrying one copy of AlbCre were then interbred with $\mathrm{fl} /$ + littermates lacking Cre to generate liver-specific PPAR $\gamma$ conditional-null mice and littermate control mice. PPAR $\gamma(f l / f l) \mathrm{AlbCre}^{+}$or PPAR $\gamma(f l / f l) \mathrm{AlbCre}^{-}$mice were intercrossed with heterozygotic C57BL/6J-Lep $p^{o b}$ mice obtained from The Jackson Laboratory (Bar Harbor, Maine) to generate double heterozygotes (PPAR $\gamma$ $f l /+, O B / o b)$. Since mouse PPAR $\gamma$ and leptin are both on chromosome 6 , the double heterozygotes were crossed until recombination occurred to generate $O B / o b$-PPAR $\gamma(f l / f l)$ genotype mice. The OB/obPPAR $\gamma(f l / f l) \mathrm{AlbCre}^{+}$or $O B / o b-\mathrm{PPAR} \gamma(f l / f l) \mathrm{AlbCre}^{-}$ mice were then crossed to generate $o b / o b$-PPAR $\gamma$ $(f l / f l) \mathrm{AlbCre}^{+}$or $o b / o b$-PPAR $\gamma(f l / f l)$ AlbCre ${ }^{-}$mice. Mice were reared on a 12-hour light/dark cycle and fed water and a pellet chow diet (NIH-07) ad libitum. For rosiglitazone (SmithKline Beecham Pharmaceuticals, West Sussex, United Kingdom) treatment, a powdered diet (AIN-93G; Dyets Inc., Bethlehem, Pennsylvania, USA) was blended with the drug and administered for 3 weeks at approximately $3 \mathrm{mg} / \mathrm{kg} /$ day. The National Cancer Institute Animal Care and Use Committee approved all animal studies, which were carried out in accordance with Institute of Laboratory Animal Resources (ILAR) guidelines.

$D N A$ and RNA analysis. Southern and Northern blot analysis and RNase protection assays were performed as previously described (4). The cDNA probes used for Northern blotting were described in previous reports (4, 23) except for the probes indicated below. cDNA probes for malic enzyme (MAL), ATP-citrate lyase (ACL), and glycerol-3-phosphate acyltransferase (GPAT) were amplified by PCR from a mouse liver cDNA library using gene-specific primers and cloned into PGEM-T Easy Vector (Promega Corp., Madison, Wisconsin, USA). The primers used for PCR were as follows. MAL
5', CGATGATAAGGTCTTCCTCACCAC and 3', TCCTATGGAGTGTTTGGGTTCG. ACL 5', GGTCAATCTCTCTCTGGATGGAGT and 3', GGATGGTCTTGGCATAGTCATAGG. GPAT 5', CGAAGGTCACTACAATGGCGAAC and 3', GGTCTCTTTGAAAACCCCGATG. The identities of the probes were confirmed by nucleotide sequencing.

Measurement of lipids, lipoprotein lipase activity, VLDL export, and insulin. Serum lipid levels and lipoproteins were analyzed as previously described (4). The clearance rate of exogenous triglyceride (TG) was measured in mice fasted for 4 hours and then gavaged with $400 \mu \mathrm{l}$ of olive oil. Blood was taken at $0,60,90,270$, and 390 minutes after administration of oil, and plasma TGs were measured. For liver TG and cholesterol concentrations, total lipids were extracted from $100 \mathrm{mg}$ liver as previously described (24) and the extracts were used for the measurement of each lipid class. Postheparin lipoprotein and hepatic lipase activities were assayed in triplicate using ${ }^{14} \mathrm{C}$-labeled triolein substrate as previously described (25). Postheparin plasma was collected as previously described (25). VLDL export rates were measured according to an earlier method (26). Plasma insulin was measured with a radioimmunoassay kit (Linco Research Inc., St. Charles, Missouri, USA).

Glucose levels and glucose tolerance tests. Glucose tolerance tests, performed on conscious mice following a 6-hour fast, were done by intraperitoneal administration of glucose $(2 \mathrm{mg} / \mathrm{g})$. Blood samples were taken at $0,30,60,90$, and 120 minutes from the tail vein and were analyzed for glucose concentrations using a Glucometer Elite (Bayer Corp., Elkhart, Indiana, USA).

Histology. Livers from 7- to 8-week-old representative mice were fixed in $10 \%$ neutral buffered formalin and embedded in paraffin. Sections were cut at a thickness of 4-6 $\mu \mathrm{m}$ and stained with H\&E.

Hyperinsulinemic-englycemic clamp. The clamp studies were performed using 5-week-old male $o b / o b$ mice using the protocol previously described (27).

\section{Results}

Production of a liver-specific PPAR $\gamma$-null mouse on an ob/ob background. The conditional floxed allele of the PPAR $\gamma$ gene (Figure 1a) was described in a previous report (4). No difference in phenotype was noted between 15-weekold PPAR $\gamma(f l / f l) \mathrm{AlbCre}^{-}$and PPAR $\gamma(f l / f l) \mathrm{AlbCre}^{+}$mice, probably reflecting the low level of PPAR $\gamma$ expression in liver of nonobese wild-type mice $(10,15,28)$. To elucidate the role of PPAR $\gamma$ in liver, PPAR $\gamma(f l / f l)$ AlbCre mice were crossed with $o b / o b$ mice. The $o b / o b$-PPAR $\gamma(f l / f l)$ AlbCre $^{-}$ and $o b / o b$-PPAR $\gamma(f l / f l)$ AlbCre ${ }^{+}$mice thus obtained had a distribution of offspring genotypes that followed the predicted mendelian frequencies. These crosses also generated lean mice, wild type for the leptin gene, from the same litter, designated $O B / O B$-PPAR $\gamma(f l / f l) \mathrm{AlbCre}^{-}$and $O B / O B-P P A R \gamma(f l / f l) A l b C r e^{+}$.

To examine liver-specific deletion of the floxed exon 2 of the PPAR $\gamma$ gene, the recombination event was analyzed by Southern blotting of genomic DNA isolated from various tissues using a $3^{\prime}$ probe (Figure 1a). Dele- 
tion of exon 2 was found to occur in liver in a Cre ${ }^{+}$-specific manner, as indicated by the presence of an $8-\mathrm{kb}$ hybridizing band that represents the PPAR $\gamma$ allele lacking exon 2. However, in addition to the deleted band, the intact floxed exon 2 allele, represented by a $10-\mathrm{kb}$ band, was also detected in the PPAR $\gamma(f l / f l) \mathrm{AlbCre}^{+}$mice (Figure 1b). The incomplete deletion is probably the result of nonparenchymal cells such as Kupffer, endothelial, and stellate cells that do not express the albumin promoter, as noted in previous reports $(22,29)$. The loss of full-length PPAR $\gamma$ mRNA and the presence of a truncated PPAR $\gamma$ mRNA product was confirmed in $o b / o b$-PPAR $\gamma(f l / f l) \mathrm{AlbCre}^{-}$and $o b / o b$-PPAR $\gamma(f l / f l) \mathrm{AlbCre}^{+}$ liver using RNase protection assays (Figure 1c). The truncated PPAR $\gamma$ transcripts were detected only in $\mathrm{Cre}^{+}$ mice. Using an $\beta$-actin riboprobe to normalize for the amount of total RNA, the mRNA levels of PPAR $\gamma$ in $o b / o b$-PPAR $\gamma(f l / f l) \mathrm{AlbCre}^{-}$mice were shown to be markedly higher than in $O B / O B-P P A R \gamma(f l / f l) \mathrm{AlbCre}^{-}$ mice. In addition, PPAR $\gamma(f l / f l)$ AlbCre $^{+}$-derived mRNA levels in both $O B / O B$ and $o b / o b$ mice were significantly lower than native PPAR $\gamma$ transcripts, suggesting the possibility that the truncated mRNA is inherently less stable than wild-type PPAR $\gamma$ mRNA (4) or that PPAR $\gamma$ expression is self-regulated (30).

The deficiency of liver-specific PPAR $\gamma$ improves fatty liver in ob/ob mice. The ob/ob genetic background causes severe obesity and a fatty liver. To assess the potential effects of liver-specific PPAR $\gamma$ deficiency, body and tissue weights were measured. For a period of 8 weeks after birth, no significant difference in body and white adipose weight was observed between ob/ob$\operatorname{PPAR} \gamma(f l / f l) \mathrm{AlbCre}^{-}$and $o b / o b$-PPAR $\gamma(f l / f l) \mathrm{AlbCre}^{+}$ mice (Table 1). However, the liver weight of $o b / o b$ $\operatorname{PPAR} \gamma(f l / f l) \mathrm{AlbCre}^{+}$mice was significantly lower than that of $o b / o b$-PPAR $\gamma(f l / f l) \mathrm{AlbCre}^{-}$mice; the $O B / O B-$ $\operatorname{PPAR} \gamma(f l / f l) \mathrm{AlbCre}^{-}$and $O B / O B-\operatorname{PPAR} \gamma(f l / f l) \mathrm{AlbCre}^{+}$ livers were not different. These results suggest that PPAR $\gamma$ has a physiological function in the liver of $o b / o b$ mice. Livers in the $o b / o b$-PPAR $\gamma(f l / f l) \mathrm{AlbCre}^{-}$mice were significantly enlarged relative to those of $O B / O B$ $\operatorname{PPAR} \gamma(f l / f l) \mathrm{AlbCre}^{-}$mice and were yellowish in appearance, typical of fatty liver (Figure 2a). However, $o b / o b$ PPAR $\gamma(f l / f l)$ AlbCre $^{+}$mice had a dramatically improved fatty liver. Therefore, the elevated PPAR $\gamma$ expression in $o b / o b$ liver appears to be a pathophysiological response to the state of severe obesity and diabetes. At this time, no phenotypic differences have been seen between $O B / O B$-PPAR $\gamma(f l / f l) \mathrm{AlbCre}^{-}$and OB/OB-PPAR $\gamma(f l / f l)-$ $\mathrm{AlbCre}^{+}$mice. Histological analysis of the liver from each genotyped mouse revealed the presence of numerous hepatocyte vacuoles in the $o b / o b$-PPAR $\gamma$ $(f l / f l)$ AlbCre- liver; hepatocyte vacuoles observed in the $o b / o b$-PPAR $\gamma(f l / f l)$ AlbCre $^{+}$liver were much smaller and less numerous than those seen in $o b / o b-\operatorname{PPAR} \gamma$ $(f l / f l)$ AlbCre- liver (Figure 2, b-e). These vacuoles were positive for the presence of lipid as revealed by oil red O staining (data not shown) or measurement of hepatic TG content. The hepatic TG content of $o b / o b$ -
$\operatorname{PPAR} \gamma(f l / f l) \mathrm{AlbCre}^{+}$mice was also significantly lower (75\% lower) than that of $o b / o b$-PPAR $\gamma(f l / f l) \mathrm{AlbCre}^{-}$ mice (Figure 2f). Rosiglitazone treatment of $o b / o b$ $\operatorname{PPAR} \gamma(f l / f l)$ AlbCre- mice caused a marked increase in hepatic TG content and size compared with ob/obPPAR $\gamma(f l / f l) A l b C r e^{+}$mice (Figure 2g). Histological data also revealed numerous large hepatocyte vacuoles (Figure 2, h-k). However, these effects of rosiglitazone on liver were not observed in $\mathrm{Cre}^{+}$mice. The TG content and liver weight in $o b / o b$-PPAR $\gamma(f l / f l)$ AlbCre $^{+}$mice were $8.5 \%$ and $33 \%$ that of rosiglitazonetreated $o b / o b$-PPAR $\gamma(f l / f l) \mathrm{AlbCre}^{-}$mice, respectively (Figure 2,1 and $\mathrm{m}$ ). These results strongly suggest that

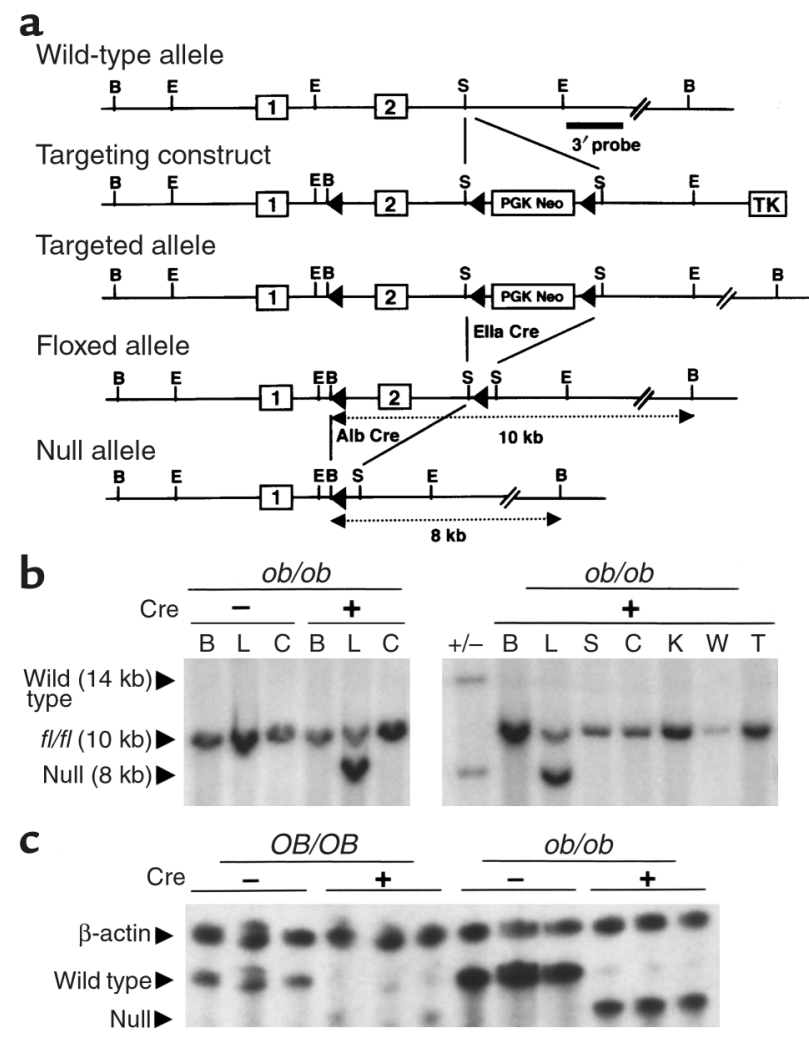

\section{Figure 1}

Gene targeting and conditional deletion of exon 2 of the PPAR $\gamma$ gene. (a) Restriction maps of the wild-type allele, targeting vector, targeted allele, floxed allele, and null allele. The indicated 3' probe was used to assess recombination events by Southern blot analysis. Open boxes represent exons and are numbered as indicated. PGK neomycin (PGK $\mathrm{Neo}$ ) and thymidine kinase (TK) are positive and negative selection cassettes, respectively. Restriction sites: B, BamHI; E, EcoRI; S, Sacl. (b) Southern blot analysis of BamHI-digested genomic DNA isolated from brain (B), liver (L), colon (C), spleen (S), kidney (K), white adipose $(\mathrm{W})$, and tail (T) in ob/ob-PPAR $\gamma(f l / f I) \mathrm{AlbCre}^{+}$or $o b / o b-P P A R \gamma-$ (fl/fl)AlbCre- mice. Fragments hybridizing with 3' probe from the wildtype, floxed, and deleted alleles migrate at approximately 14, 10, and $8 \mathrm{~kb}$, respectively. (c) RNase protection analysis of PPAR $\gamma$ mRNA in $O B / O B$ - or $o b / o b$-PPAR $\gamma(f l / f l) A l b C r e$ mouse livers. Total RNA from three separate mouse livers in each genotype were hybridized with riboprobes for $\beta$-actin and PPAR $\gamma$. The products were then separated on a $5.0 \%$ polyacrylamide gel. The size of the protected mRNA fragments for PPAR $\gamma$ and $\beta$-actin is as follows; wild-type PPAR $\gamma, 195 \mathrm{nt}$; null PPAR $\gamma, 165$ nt; and $\beta$-actin; 250 nt. 
Table 1

Tissue weight and blood parameters in hepatic PPAR $\gamma$-deficient $o b / o b$ mice

\begin{tabular}{lcccc}
\hline & \multicolumn{3}{c}{ OB/OB } & \multicolumn{2}{c}{ ob/ob } \\
Cre & - & + & - & + \\
Age (weeks) & $7.30 \pm 0.25(9)$ & $7.81 \pm 0.20(23)$ & $7.75 \pm 0.47(8)$ & $7.72 \pm 0.17(24)$ \\
Body weight (g) & $16.8 \pm 0.59(9)$ & $17.7 \pm 1.3(23)$ & $30.2 \pm 1.6(8)$ & $31.5 \pm 1.2(24)$ \\
Liver weight (g) & $0.61 \pm 0.1(9)$ & $0.71 \pm 0.1(23)$ & $1.5 \pm 0.1(8)$ & $1.2 \pm 0.1(24)^{\mathrm{A}}$ \\
Liver/body (\%) & $4.08 \pm 0.1(9)$ & $3.89 \pm 0.2(9)$ & $4.92 \pm 0.4(8)$ & $3.94 \pm 0.1(24)^{\mathrm{C}}$ \\
Epididymal fat (g) & $0.28 \pm 0.0(9)$ & $0.30 \pm 0.0(23)$ & $1.8 \pm 0.3(8)$ & $2.1 \pm 0.1(24)$ \\
Inguinal fat (g) & $0.07 \pm 0.0(9)$ & $0.09 \pm 0.0(23)$ & $0.4 \pm 0.1(8)$ & $0.5 \pm 0.0(24)$ \\
$\beta$-HBA (mg/dl) & $21.8 \pm 3.8(6)$ & $22.7 \pm 6.2(6)$ & $13.9 \pm 3.2(6)$ & $11.6 \pm 3.2(6)$ \\
Serum FFA (mM) & $1.29 \pm 0.05(6)$ & $1.26 \pm 0.20(6)$ & $1.18 \pm 0.20(6)$ & $1.88 \pm 0.30(6)^{\mathrm{A}}$ \\
Serum TG (mg/dl) & $58.1 \pm 4.3(6)$ & $61.5 \pm 5.1(6)$ & $63.6 \pm 10(6)$ & $144 \pm 28(6)^{\mathrm{A}}$ \\
Serum CHO (mg/dl) & $97.3 \pm 13(6)$ & $142 \pm 14(6)$ & $189 \pm 13(6)$ & $220 \pm 14(6)^{\mathrm{B}}$ \\
Serum PL (mg/dl) & $148 \pm 20(6)$ & $202 \pm 15(6)$ & $227 \pm 9.7(6)$ & $298 \pm 17(6)^{\mathrm{B}}$
\end{tabular}

Values are mean \pm SE. Numbers of animals are indicated in parentheses. After a 24-hour fast, animals were sacrificed. HBA, hydroxybutyrate; TG, total TG; $\mathrm{CHO}$, total cholesterol; $\mathrm{PL}$, phospholipid. ${ }^{\mathrm{A} P}<0.05$; ${ }^{\mathrm{B} P}<0.01$; $\mathrm{C} P<0.001, \mathrm{Cre}^{-}$vs. $\mathrm{Cre}^{+}$.

hepatic PPAR $\gamma$ is involved in the development of fatty liver in $o b / o b$ mice.

Hepatic PPAR $\gamma$ controls the expression of lipogenic genes in $o b / o b$ mice. The PPAR $\gamma$-mediated transactivation of several genes involved in lipid metabolism and transport has been demonstrated $(4,10)$. However, these studies analyzed adipose tissue or macrophages that highly express PPAR $\gamma$. PPAR $\gamma$-regulated gene expression in liver remains unclear. To uncover genes regulated by hepatic PPAR $\gamma$ and to determine the mechanism of the decrease in hepatic TGs in $o b / o b$ mice lacking expression of PPAR $\gamma$, mRNA from livers of untreated (Figure 3a) and rosiglitazone-treated (Figure $3 \mathrm{~b})$ mice was analyzed. The mRNA levels of the fatty acid synthase (FAS), acetyl-CoA carboxylase $(A C C)$, ATP-citrate lyase $(A C L)$, malic enzyme $(M A L)$, glycerol-3-phosphate acyltransferase (GPAT), and stearoyl-CoA desaturase-1 (SCD1) genes in ob/obPPAR $\gamma(f l / f l) \mathrm{AlbCre}^{+}$mice were clearly lower than that of $o b / o b$-PPAR $\gamma(f l / f l) \mathrm{AlbCre}^{-}$mice. However, their expression levels were unchanged in $O B / O B$-PPAR $\gamma$ $(f l / f l) \mathrm{AlbCre}^{-}$or $\mathrm{OB} / \mathrm{OB}$-PPAR $\gamma(f l / f l) \mathrm{AlbCre}^{+}$mice. Rosiglitazone treatment additively induced the expression of ACC, MAL, GPAT, CD36, and aP2 mRNA in $o b / o b$-PPAR $\gamma(f l / f l)$ AlbCre ${ }^{-}$mice but not in $\mathrm{Cre}^{+}$mice (Figure $3 \mathrm{~b}$ ). The $a P 2$ gene was not expressed in $o b / o b$ PPAR $\gamma(f l / f l)$ AlbCre- livers of untreated mice (data not shown). The mRNA levels of genes associated with glucose metabolism, apolipoprotein receptors, and apolipoproteins were unchanged by loss of PPAR $\gamma$ (data not shown). Since the lipogenic genes that were induced in $o b / o b$-PPAR $\gamma(f l / f l) \mathrm{AlbCre}^{-}$mice are directly or indirectly involved in fatty acid and TG synthesis, these results suggest that hepatic PPAR $\gamma$ in $o b / o b$ mice regulates TG content by controlling lipid synthesis. Further, other transcription factors that regulate the expression of lipogenic genes were analyzed. However, no difference in expression between $o b / o b$ PPAR $\gamma(f l / f l) \mathrm{AlbCre}^{-}$and $\mathrm{Cre}^{+}$mice was observed for the SREBP, liver $\mathrm{X}$ receptor$\alpha(L X R \alpha)$, or PPAR $\alpha$ genes (Figure 3, a and b).

The deficiency of liver-specific PPAR $\gamma$ causes accumulation of VLDL and an elevation of FFA content in the ob/ob mouse. The serum lipid contents of $o b / o b$-PPAR $\gamma(f l / f l)$ AlbCre $^{-}$and $o b / o b$-PPAR $\gamma$ $(f l / f l) \mathrm{AlbCre}^{+}$mice are summarized in Table 1. Levels of all lipid classes (TG, FFA, cholesterol, and phospholipids), of $o b / o b$ PPAR $\gamma(f l / f l)$ AlbCre $^{+}$mice were significantly higher than those of $o b / o b$-PPAR $\gamma$ $(f l / f l)$ AlbCre ${ }^{-}$mice after 24 hours of fasting. Contrary to this result, no significant difference was observed in the two $O B / O B$-PPAR $\gamma(f l / f l)$ AlbCre mouse groups. To more precisely characterize the nature of the serum lipids and their associated lipoproteins in $o b / o b$-PPAR $\gamma(f l / f l)$ AlbCre $^{+}$mice, FPLC analysis was performed on 24-hour fasting serum. The elution profile by TG content revealed that the majority of the serum TG in $o b / o b-\mathrm{PPAR} \gamma(f l / f l) \mathrm{AlbCre}^{+}$mice results from VLDL (Figure 4a). Consistent with these data, Western blot analysis of the apolipoprotein content of the VLDL, LDL, and HDL fractions revealed that $o b / o b$-PPAR $\gamma(f l / f l) \mathrm{AlbCre}^{+}$mice have increased apoB, apoE, and apoA in the VLDL fractions compared with $o b / o b$-PPAR $\gamma(f l / f l) A l b C r e^{-}$mice (Figure $4 \mathrm{~b}$, inset). Elution profiles determined by cholesterol content revealed that LDL and HDL are also elevated in $o b / o b$ PPAR $\gamma(f l / f l) \mathrm{AlbCre}^{+}$mice (Figure $4 \mathrm{~b}$ ). The elevation of these lipoproteins appears to explain the elevation of cholesterol and phospholipid content in ob/obPPAR $\gamma(f l / f l) \mathrm{AlbCre}^{+}$mice (Table 1). The accumulation of VLDL in $o b / o b$-PPAR $\gamma(f l / f l) A l b C r e^{+}$mice raised questions about the potential for catabolism of exogenous TG-rich apolipoproteins as chylomicrons. To investigate this possibility, mice were gavaged with olive oil, and serum TG was sequentially measured (Figure 4c). The elevated rate of serum TG in $o b / o b$ PPAR $\gamma(f l / f l)$ AlbCre ${ }^{+}$mice showed a tendency toward slower clearance than in $\mathrm{Cre}^{-}$mice, although this difference did not reach statistical significance. These results suggest that the deficiency of hepatic PPAR $\gamma$ causes an impairment of TG-rich lipoprotein clearance. Furthermore, to elucidate potential mechanisms for increased serum TG and FFA in $o b / o b$ PPAR $\gamma(f l / f l) A l b C r e^{+}$mice, lipase activities and VLDL export rates were measured. However, no significant differences in the lipoprotein lipase (Figure 4d) and VLDL export rates (Figure 4e) were observed between $o b / o b-\operatorname{PPAR} \gamma(f l / f l) \mathrm{AlbCre}^{-}$and $o b / o b-\operatorname{PPAR} \gamma(f l / f l)-$ $\mathrm{AlbCre}^{+}$mice. However, hepatic lipase activity was sig- 
a
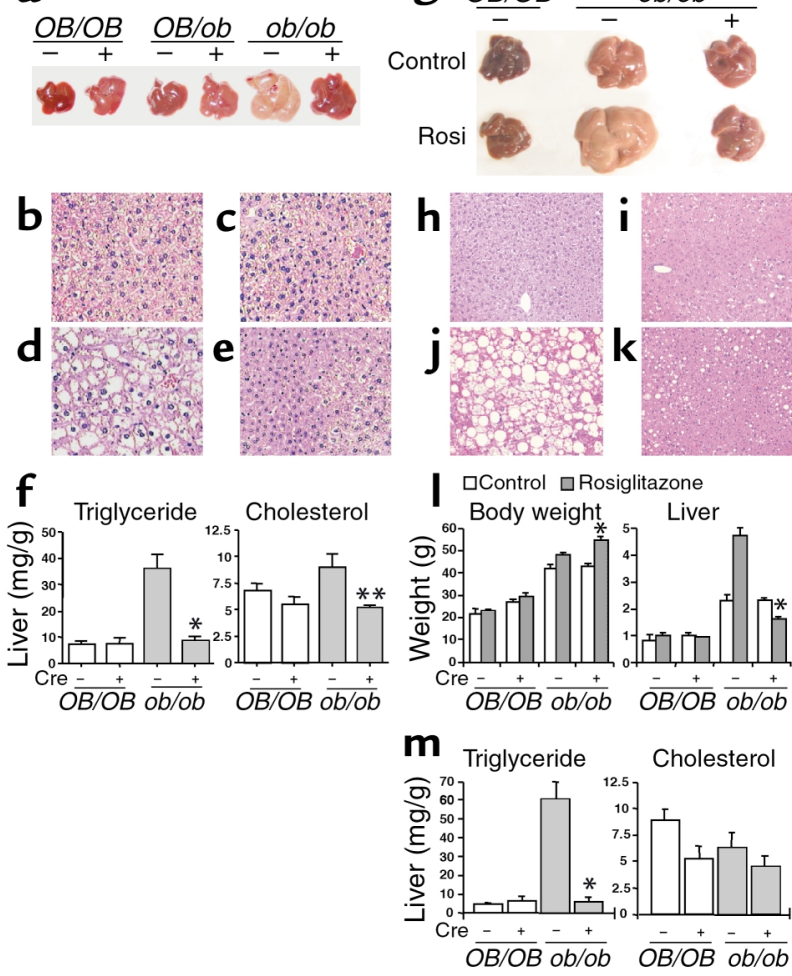
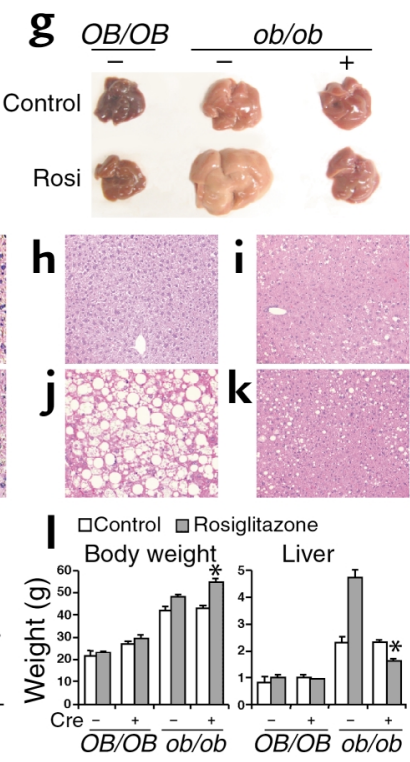

| $\square$ Control $\square$ Rosiglitazone

\section{Figure 2}

Effect of hepatic PPAR $\gamma$ deficiency in $o b / o b$ and $O B / O B$ mice. (a-f) Nontreatment mice. (a) Liver of littermates. Livers of 8-week-old mice were used. (b-e) Histology of livers from $O B / O B-P P A R \gamma(f l / f l) A l b C r e-$ (b) and $o b / o b-\operatorname{PPAR} \gamma(f l / f l) A \mathrm{lbCre}-(\mathbf{d})$ or OB/OB-PPAR $\gamma(f l / f l) \mathrm{AlbCre}^{+}$ (c) and ob/ob-PPAR $\gamma(f l / f I) A l b C r e^{+}$mice (e). H\&E staining was performed for liver sections (original magnification, $\times 100$ ) from each genotyped mouse. (f) Total cholesterol and TG content in $O B / O B$ PPAR $\gamma(f l / f l) A_{l b C r e}-(n=5: 2$ males and 3 females), OB/OB-PPAR $\gamma$ ( $f l / f l) A l b C r e^{+}(n=4: 2$ males and 2 females), ob/ob-PPAR $\gamma(f l / f l)-$ AlbCre $^{-}\left(n=6: 3\right.$ males and 3 females), and $o b / o b$-PPAR $\gamma(f l / f I) A l b C r e^{+}$ ( $n=15: 8$ males and 7 females) mice. (g-m) Rosiglitazone-treated mice. (g) Rosiglitazone-treated livers. (h-k) H\&E staining of livers from rosiglitazone-treated $O B / O B-\operatorname{PPAR} \gamma(f l / f l) \mathrm{AlbCre}^{-}(\mathbf{h})$ and $o b / o b-P P A R \gamma(f l / f l) A l b C r e^{-}(\mathbf{j})$ or OB/OB-PPAR $\gamma(f l / f l) \mathrm{AlbCre}^{+}(\mathbf{i})$ and $o b / o b$-PPAR $\gamma(f l / f l) A l b C r e^{+}$mice $(\mathbf{k})$. (I) Body and liver weight in rosiglitazone-treated and control mice. For control groups: $O B / O B-$ $\operatorname{PPAR} \gamma(f l / f l) A l b C r e^{-}, n=4$ (2 males and 2 females); OB/OB$\operatorname{PPAR}(f l / f l) \mathrm{AlbCre}^{+}(n=3$, males $) ; o b / o b-\operatorname{PPAR} \gamma(f l / f l) \mathrm{AlbCre}^{-}, n=7$ (3 males and 4 females); and ob/ob-PPAR $\gamma(f l / f l) A l b C r e^{+}, n=5$ ( 3 males and 2 females). Rosiglitazone groups: OB/OB-PPAR $\gamma$ $(f l / f l)$ AlbCre $^{-}, n=5$ ( 2 males and 3 females); OB/OB-PPAR $\gamma(f l / f l)$ $\mathrm{AlbCre}^{+}, n=4$ ( 3 males and 1 female); ob/ob-PPAR $\gamma(f l / f l) A l b C r e^{-}$, $n=10$ ( 6 males and 4 females); and ob/ob-PPAR $\gamma(f l / f l) \mathrm{AlbCre}^{+}, n=9$ ( 5 males and 4 females). ( $\mathbf{m}$ ) Total cholesterol and TG content in rosiglitazone-treated mice. The mouse number for each genotype was described in I. Data are mean \pm SE. ${ }^{*} P<0.001,{ }^{*} P<0.01 \mathrm{com}$ pared with $\mathrm{Cre}^{-}$mice. Rosi, rosiglitazone. nificantly increased in $o b / o b$-PPAR $\gamma(f l / f l) \mathrm{AlbCre}^{+}$mice (Figure 4d). The result of Northern blotting showed that, with the exception of one mouse, hepatic lipase mRNA in $o b / o b$-PPAR $\gamma(f l / f l)$ AlbCre $^{-}$liver is lower than in $O B / O B$-PPAR $\gamma(f l / f l) A l b C r e^{-}$mice. This result is in agreement with an earlier report (31). Furthermore, the deficiency of hepatic PPAR $\gamma$ resulted in recovery of hepatic lipase expression to levels similar to those found in $O B / O B$-PPAR $\gamma(f l / f l)$ AlbCre- mice (Figure $4 \mathrm{f}$ ), suggesting that the different activities between $o b / o b$ PPAR $\gamma(f l / f l) \mathrm{AlbCre}^{-}$and $\mathrm{Cre}^{+}$mice result from the differences in transcriptional levels.

Deficiency of liver-specific PPAR yaggravates hyperglycemia and insulin resistance in ob/ob mice. To assess the effects of deficiency of liver-specific PPAR $\gamma$ on glucose homeostasis, the level of blood glucose was measured (Figure 5a). Glucose levels of $o b / o b$-PPAR $\gamma(f l / f l) \mathrm{AlbCre}^{+}$mice were significantly higher than those of $o b / o b$-PPAR $\gamma(f l / f l) \mathrm{AlbCre}^{-}$ mice. To further characterize glucose metabolism, glucose tolerance tests were performed following an exogenous load of glucose. The glucose levels in $o b / o b$ $\operatorname{PPAR} \gamma(f l / f l) \mathrm{AlbCre}^{-}$mice were higher than those in the $O B / O B$-PPAR $\gamma(f l / f l)$ AlbCre $^{-}$mice (Figure 5, b and c). Surprisingly, in $o b / o b$-PPAR $\gamma(f l / f l) A l b C r e^{+}$mice of both age groups, there was a significant elevation in blood glucose levels at all timepoints compared with $o b / o b$-PPAR $\gamma(f l / f l)$ AlbCre- mice. However, the elevated glucose levels in $o b / o b$-PPAR $\gamma(f l / f l) \mathrm{AlbCre}^{+}$mice were improved by treatment with rosiglitazone, suggesting that the effect of rosiglitazone on glucose levels does not depend on hepatic PPAR $\gamma$ (Figure 5, j and l).
No difference in insulin levels was observed between $o b / o b$-PPAR $\gamma(f l / f l) \mathrm{AlbCre}^{-}$and $o b / o b$-PPAR $\gamma(f l / f l) \mathrm{Cre}^{+}$ mice (Figure 5e), suggesting that exacerbated hyperglycemia and glucose intolerance of liver PPAR $\gamma$-deficient mice may be caused by further impairment in insulin sensitivity. To directly measure the changes in insulin sensitivity in $o b / o b$-PPAR $\gamma(f l / f l) \mathrm{AlbCre}^{-}$and $o b / o b-\mathrm{PPAR} \gamma(f l / f l)$ AlbCre ${ }^{+}$mice, a hyperinsulinemic-euglycemic clamp study was performed (Figure 5, f-i). Whole-body glucose uptake (g) under hyperinsulinemic conditions is largely considered a measure of muscle insulin sensitivity. This variable was approximately $40 \%$ higher in $o b / o b$-PPAR $\gamma$ AlbCre ${ }^{-}$mice than in $o b / o b$ PPAR $\gamma(f l / f l) \mathrm{AlbCr}^{+}$mice, indicating a worsening of muscle insulin sensitivity in $o b / o b$-PPAR $\gamma(f l / f l)$ AlbCre $^{+}$ mice. The measurement of tissue glucose uptake revealed that white adipose (h) and muscle (i) glucose uptake was also lower in $o b / o b-\mathrm{PPAR} \gamma(f l / f l) \mathrm{AlbCre}^{+}$mice than in $o b / o b$-PPAR $\gamma(f l / f l)$ AlbCre $^{-}$mice. In contrast, $o b / o b$-PPAR $\gamma(f l / f l)$ AlbCre $^{+}$mice had more pronounced suppression of endogenous glucose production during the clamp, suggesting that liver insulin sensitivity is improved by the deficiency of hepatic PPAR $\gamma$.

Rosiglitazone improves the plasma diabetic syndromes in hepatic PPAR $\gamma$-deficient mice. Finally, we examined the effect of rosiglitazone on symptoms of diabetes aggravated in hepatic PPAR $\gamma$-deficient mice. The glucose and TG levels were elevated and the glucose intolerance observed in $o b / o b$-PPAR $\gamma(f l / f l) \mathrm{AlbCre}^{+}$was significantly improved by treating with rosiglitazone (Figure 5, j-1 and o). Treating with rosiglitazone 


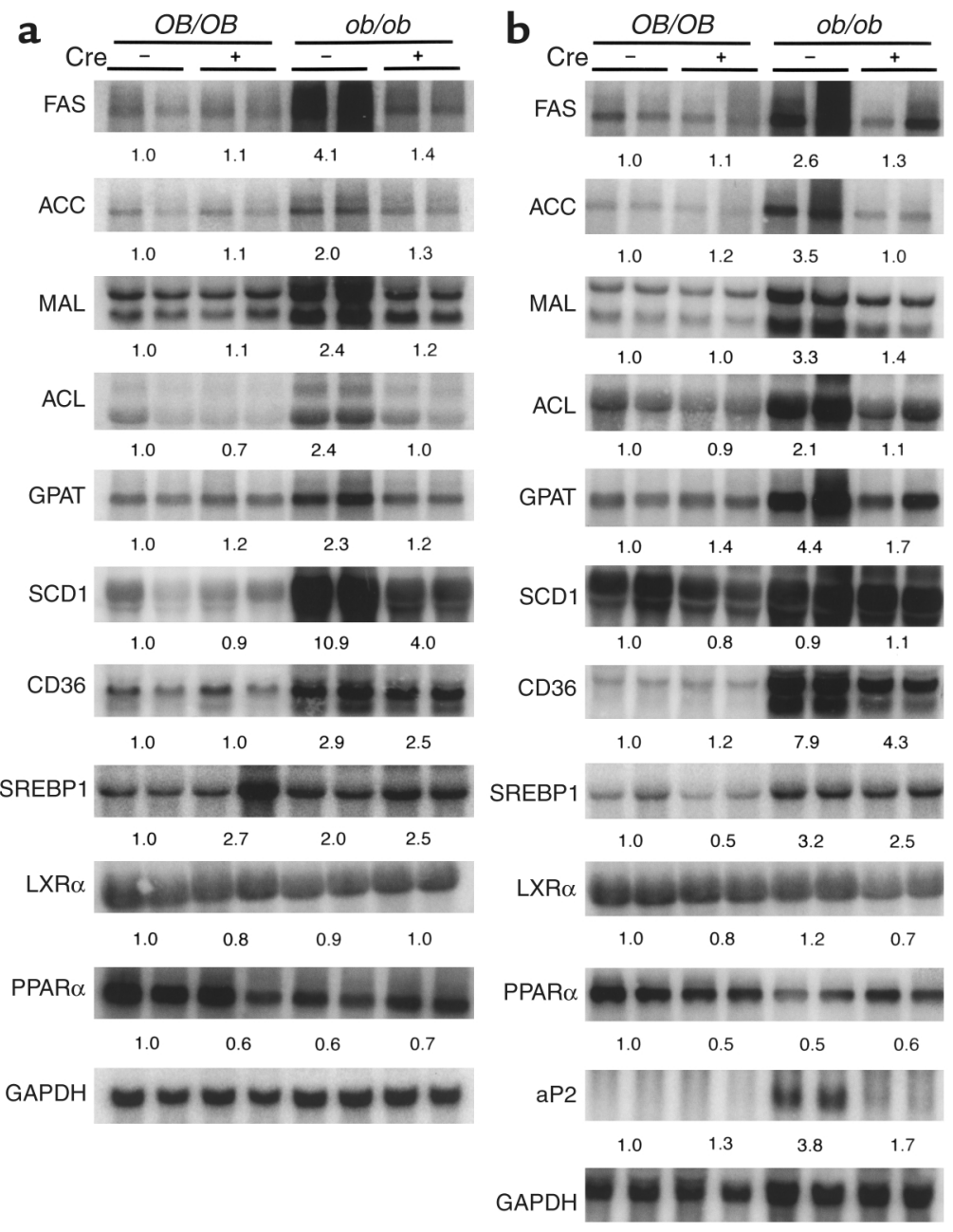

\section{Figure 3}

Northern blot analysis to assess the effect of PPAR $\gamma$ deficiency on hepatic gene expression in untreated and rosiglitazone-treated $o b / o b$ mice. Total RNA was isolated from nonfasting male mice and $20 \mu \mathrm{g}$ was subjected to electrophoresis on a 1.2\% agarose gel, transferred to a nylon membrane, and hybridized with the indicated ${ }^{32} \mathrm{P}$-labeled cDNA probes. (a) Northern blot of untreated $o b / o b$ mice liver. (b) Northern blots of rosiglitazone-treated $o b / o b$ mice liver. Quantitation of the bands was performed using the Phosphorlmager from Molecular Dynamics and are expressed as the fold change, after correction for GAPDH levels, relative to $O B / O B$ $\operatorname{PPAR} \gamma(f l / f l) \mathrm{AlbCre}^{-}$mice. Values are averages obtained from two animals.

$29.2 \% \pm 1.1 \%(n=5)$ of the total alleles $(10 \mathrm{~kb}+8 \mathrm{~kb})$, a result that is in agreement with parenchymal cell-specific deletion mediated by the AlbCre transgene. RNase protection further revealed that PPAR $\gamma$ mRNA in PPAR $\gamma(f l / f l)$ $\mathrm{AlbCre}^{+}$mice is less than 5\% that found in livers of PPAR $\gamma(f l / f l) \mathrm{AlbCre}^{-}$mice. Although truncated transcripts apparently derived from the recombined allele are detected, PPAR $\gamma$ proteins are not expected to be expressed since these transcripts have a reading frame that results in a new stop codon at amino acids 87 (PPAR $\gamma 1)$ or 117 (PPAR $\gamma 2)$. Bands corresponding to the expected translation products of PPAR $\gamma$ mRNA

showed a tendency to lower insulin and FFA levels, though this did not reach statistical significance (Figure $5, \mathrm{~m}$ and $\mathrm{n}$ ). These results suggest that the effect of rosiglitazone on the symptoms of diabetes aggravated in hepatic PPAR $\gamma$-deficient mice does not solely depend on hepatic PPAR $\gamma$.

\section{Discussion}

Deficiency of liver-specific PPAR in ob/ob mice. Southern blot analysis of tissue DNA from $o b / o b$-PPAR $\gamma(f l / f l)$ $\mathrm{AlbCre}^{-}$and $o b / o b-\mathrm{PPAR} \gamma(f l / f l) \mathrm{AlbCre}^{+}$mice revealed over $80 \%$ deletion in the $\mathrm{Cre}^{+}$liver, with no indication of recombination in other tissues. The detection of alleles that were not recombined in PPAR $\gamma(f l / f l)$ $\mathrm{AlbCre}^{+}$mice is similar to results of Southern blot analysis in $\mathrm{AlbCre}^{+}$mice generated in other studies (22, 29). This failure to recombine is believed to result from the existence of nonparenchymal cell types in the liver that do not express the albumin promoter and hence do not express Cre recombinase (29). It is known that the content of nonparenchymal cells in rat liver is approximately $30 \%$ of total cells (32). Indeed, quantitation of Southern blot signals revealed that the band representing the unrecombined floxed allele band (10 $\mathrm{kb})$ in $o b / o b$-PPAR $\gamma(f l / f l) \mathrm{AlbCre}^{+}$mouse liver represents lacking exon 2, which are approximately $10 \mathrm{kDa}$ (PPAR $\gamma 1$ ) and $13 \mathrm{kDa}$ (PPAR 2 ), did not appear on Western blots, perhaps due to instability of the prematurely truncated proteins (4).

Hepatic PPAR is critical for the development of fatty liver in ob/ob mice. The mechanisms for hepatic steatosis in $o b / o b$ mice are not well understood, but some evidence indicates that elevation of hepatic lipogenesis is involved (33). The expression of genes encoding enzymes involved in lipogenesis - FAS, ACC, MAL, $S C D 1, G P A T$, and $A C L-$ is increased in $o b / o b$ liver (34). In fact, de novo fatty acid synthesis activity measured using ${ }^{3} \mathrm{H}_{2} \mathrm{O}$ in $o b / o b$ liver is eightfold higher than in lean mice (34).

In the present study, hepatic PPAR $\gamma$ was found to have a role in development of fatty liver in $o b / o b$ mice. The results of Northern blot analysis showed that expression of the lipogenesis genes induced in $o b / o b$ PPAR $\gamma(f l / f l) \mathrm{AlbCre}^{-}$mice was attenuated in $o b / o b$ PPAR $\gamma(f l / f l) \mathrm{AlbCre}^{+}$mice. The expression levels of these genes in $o b / o b$-PPAR $\gamma(f l / f l) \mathrm{AlbCre}^{+}$mice returned to the basal levels found in $O B / O B$-PPAR $\gamma(f l / f l) A l b C r e^{-}$mice. These results indicate that hepatic PPAR $\gamma$ may modulate the amount of hepatic TG by regulating the expression levels of lipogenic genes. Rosiglitazone is repre- 

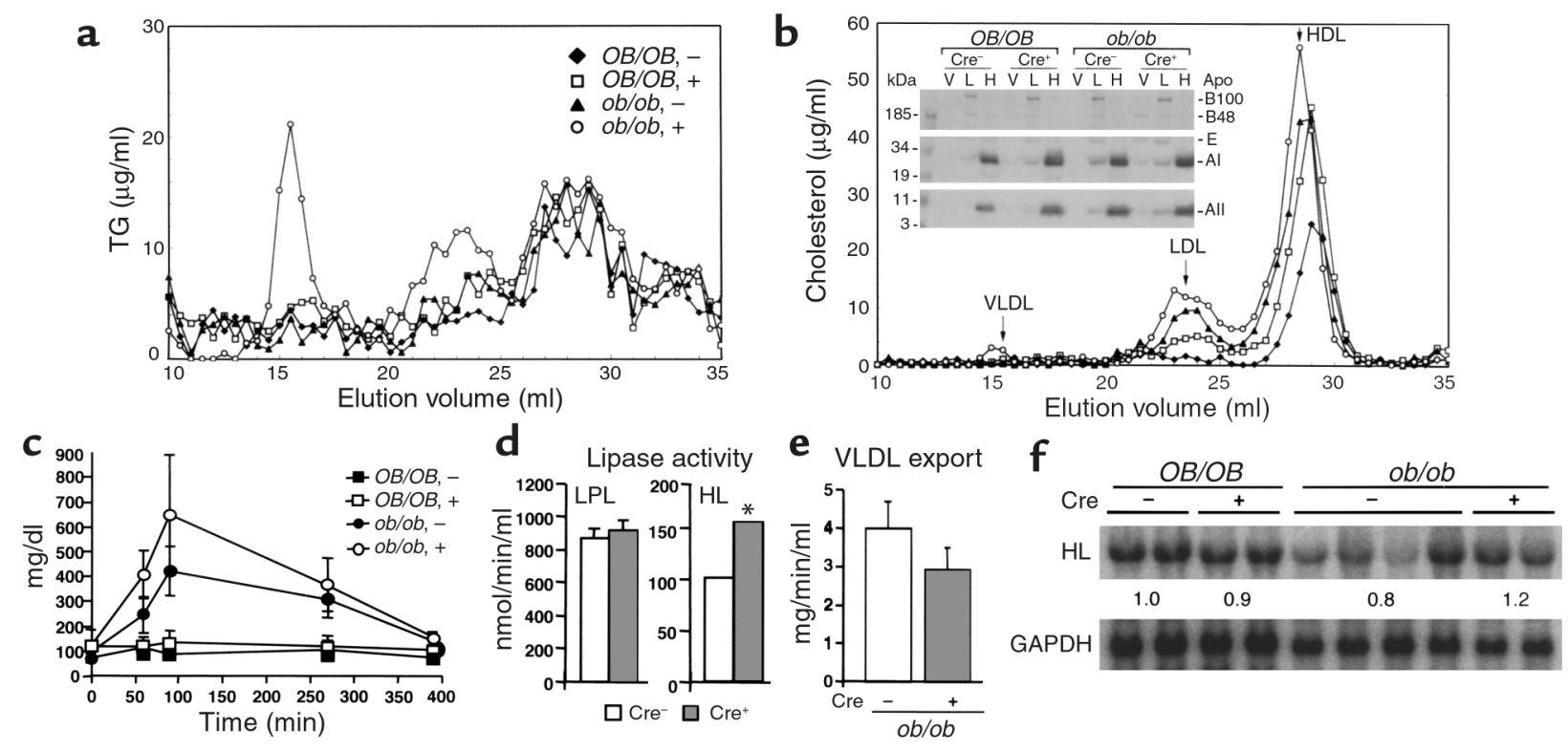

\begin{abstract}
Figure 4
Effect of PPAR $\gamma$ deficiency on the catabolism of serum TG in the $o b / o b$ mouse. Lipoproteins were separated from $60 \mu$ l of pooled mouse plasma samples ( $n=6$ for each genotype) by FPLC. The concentration ofTG $(\mathbf{a})$ and cholesterol $(\mathbf{b})$ in each eluted fraction is indicated on the $y$ axis. Inset: immunoblot analysis of apoB, apoE, apoA-I, and apoA-II contained within the VLDL (V), LDL (L), and HDL (H) top fractions from each mouse genotype. (c) Measurement of serum TG after gavage with oil. The clearance rate of exogenous TG was measured in mice fasted for 4 hours as described in Methods. (d and e) Measurement of plasma lipase activities (d) and VLDL export rates (e). In d, for $o b / o b-$ PPAR $\gamma(f l / f l) A l b C r e^{-}$mice, $n=7 ; o b / o b$-PPAR $\gamma(f l / f l) A l b C r e^{+}, n=10$. In e, for ob/ob-PPAR $\gamma(f l / f l) A l b C r e^{-}, n=7 ; o b / o b-P P A R \gamma(f l / f l) A l b C r e^{+}$, $n=6$. Each assay was performed as described in Methods. LPL, lipoprotein lipase; HL, hepatic lipase. (f) Northern blotting for hepatic lipase. The Northern blot was performed as described in the legend to Figure 3 . All data are mean $\pm \mathrm{SE} .{ }^{*} P<0.01, \mathrm{Cre}^{-}$vs. Cre ${ }^{+}$mice.
\end{abstract}

sentative of a class of antidiabetic agents that act by increasing insulin sensitivity (35); these drugs are also agonist ligands for PPAR $\gamma(36)$. Rosiglitazone treatment of $o b / o b$-PPAR $\gamma(f l / f l)$ AlbCre ${ }^{-}$mice caused exacerbation of the development of fatty liver and increased liver size; this was not observed in $\mathrm{Cre}^{+}$mice, indicating a correlation between the activation of hepatic PPAR $\gamma$ and the development of fatty liver. Furthermore, rosiglitazone induced the expression of the ACC, GPAT, $C D 36$, and $a P 2$ genes in $o b / o b$-PPAR $\gamma(f l / f l)$ AlbCre $^{-}$mice compared with untreated $o b / o b$-PPAR $\gamma(f l / f l)$ AlbCre $^{-}$ mice. Therefore, the elevation of fatty acid and TG synthesis, uptake of fatty acids, and lipid accumulation in liver may be included in possible mechanisms that result in more severe fatty liver in rosiglitazone-treated $o b / o b$-PPAR $\gamma(f l / f l)$ AlbCre- mice.

It should be noted that no obvious phenotypes were observed for OB/OB-PPAR $\gamma(f l / f l) \mathrm{AlbCre}^{+}$mice. However, the mice were not observed beyond 13 weeks of age. Therefore we cannot rule out the existence of a small, subtle phenotype yet undetected in these mice. Perhaps older mice or mice on special (high-fat) diets may cause more noticeable phenotypes to emerge.

SREBP1 proteins are basic helix-loop-helix leucine zipper family transcription factors that mainly regulate the expression of lipogenesis genes, including FAS, $A C C, M A L, S C D 1$, GPAT, and ACL (37). Overexpression of SREBP1 in transgenic mice results in fatty liver.
SREBP1-null mice on the $o b / o b$ genetic background $\left(\right.$ lep $p^{o b / o b} \times$ Srebp $1^{-/-}$mice) were produced and fatty livers were markedly attenuated (38). Similar to ob/obPPAR $\gamma(f l / f l) A l b C r e^{+}$mice, the mRNA levels of lipogenic enzymes such as FAS, SCD1, GPAT, S14, and ACL were decreased in $l e p^{o b / o b} \times$ Srebp $1^{-/-}$mice. These results indicate that SREBP1 is also an important factor for the development of fatty liver in $o b / o b$ mice.

Regulation of lipogenesis genes by bepatic PPAR $\gamma$. To our knowledge, no prior study has directly shown that PPAR $\gamma$ regulates the expression of the FAS, ACC, MAL, $S C D 1, G P A T$, and $A C L$ genes in vivo. It remains unclear whether PPAR $\gamma$ directly or indirectly regulates the transcription of these genes. It was shown that MAL (39) and SCD1 (40) are regulated by PPAR $\alpha$ and have the peroxisome proliferator response elementlike (PPRE-like) sequence in their promoter regions. Transfection analysis revealed a PPRE located at position -664 to -642 bp of the SCD1 promoter, suggesting that PPAR $\gamma$ can directly bind to a PPRE in the promoter of this gene. However, this raises questions about why PPAR $\gamma$ can specially regulate the expression of these genes when PPAR $\alpha$ is predominantly expressed in liver of $o b / o b-\operatorname{PPAR} \gamma(f l / f l) \mathrm{AlbCr}^{+}$and $o b / o b$-PPAR $\gamma(f l / f l)$ AlbCre- mice. Treatment of wildtype and PPAR $\alpha$-null mice with the highly selective PPAR $\gamma$ agonist rosiglitazone induces acyl-CoA oxidase, fatty acid-binding protein, and CYP4A mRNA's, 

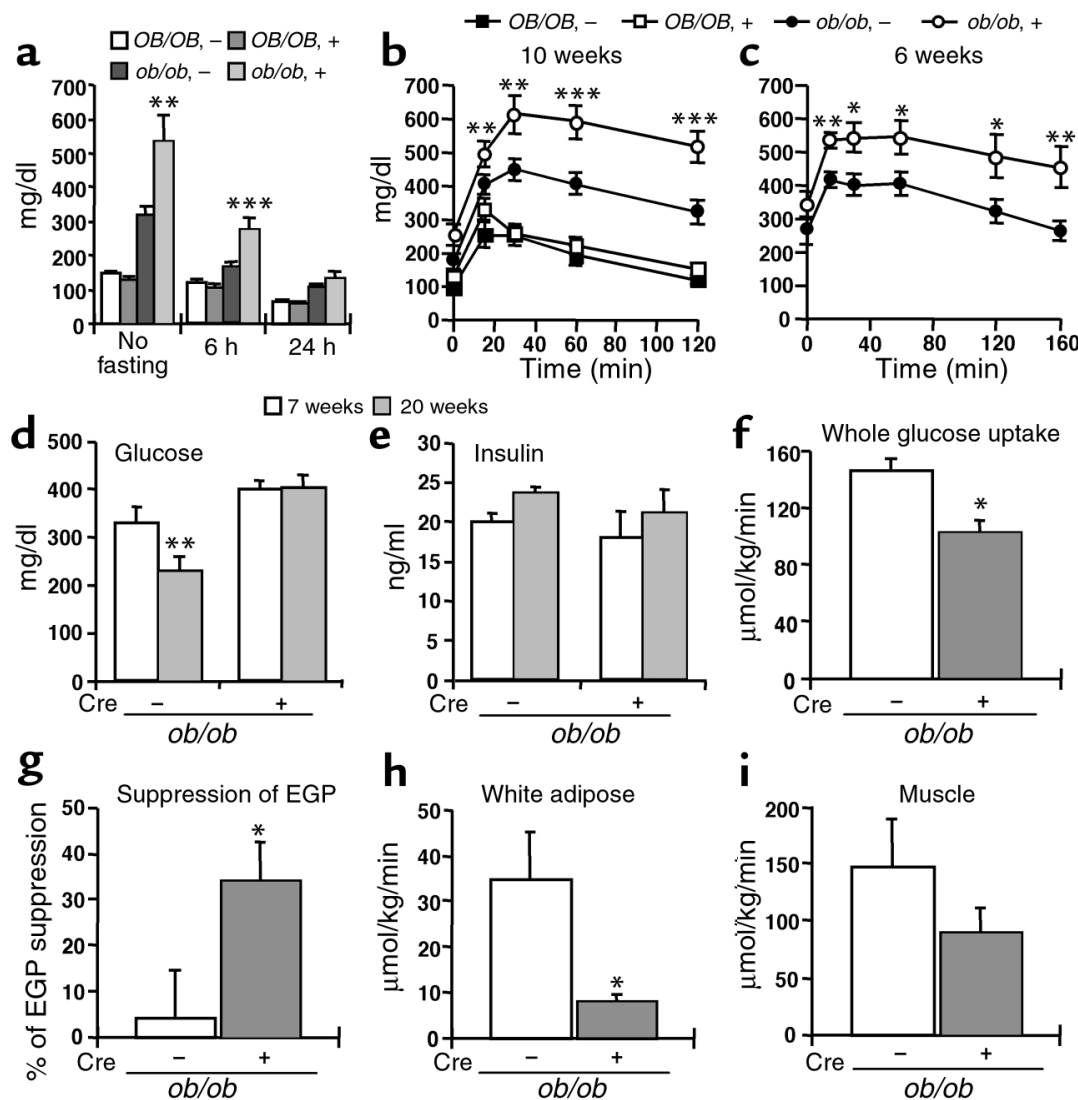

h
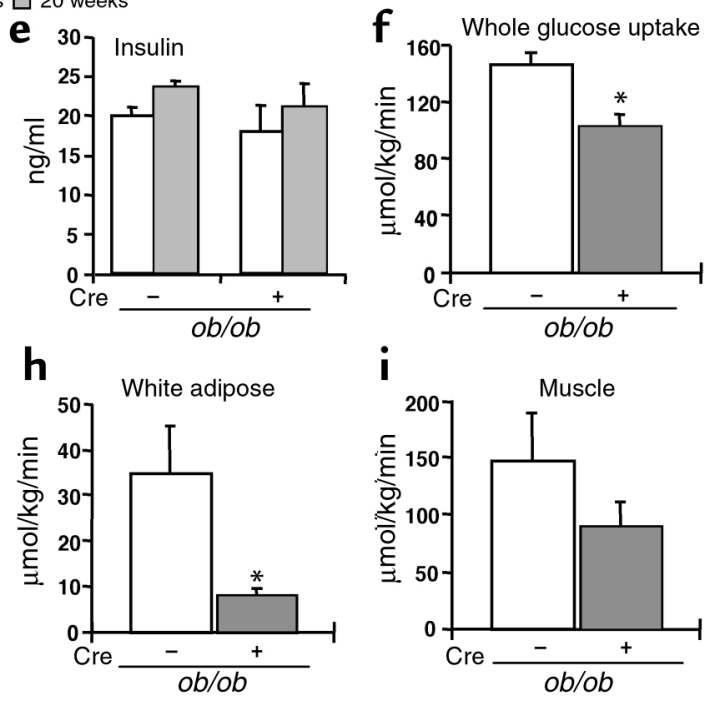

i

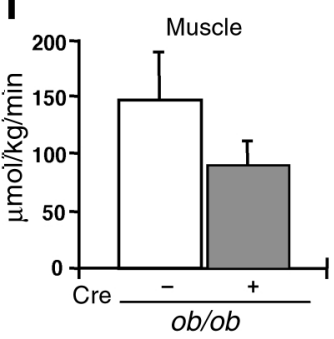

k
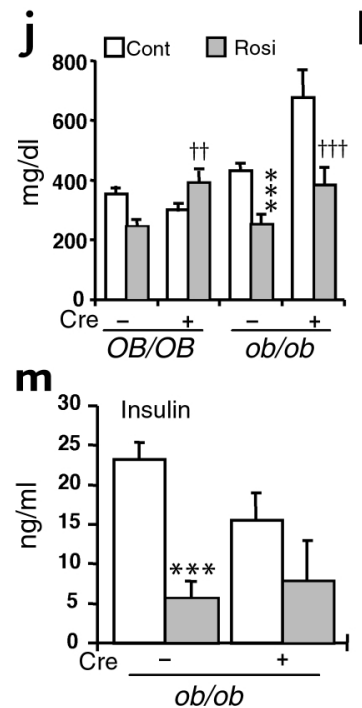
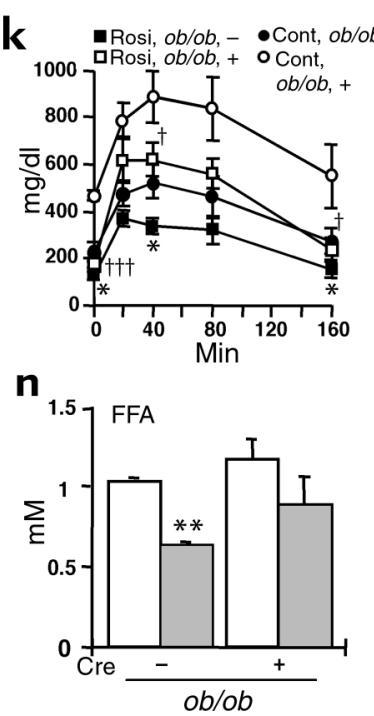
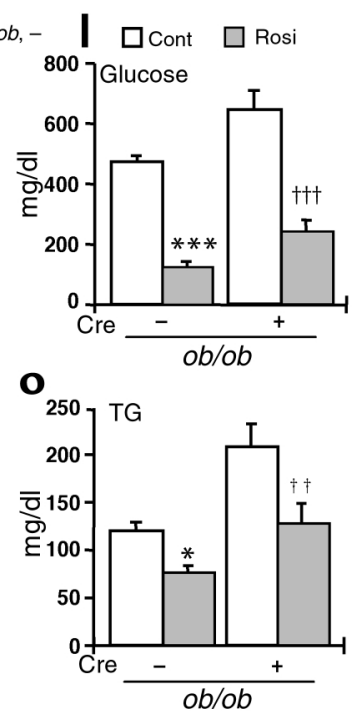

Figure 5

Effect of PPAR $\gamma$ deficiency on glucose homeostasis in the ob/ob mouse. (a) Blood glucose concentrations were measured in 10-week-old mice after no fasting and after 6 hours or 24 hours of fasting. For $O B / O B-P P A R \gamma(f l / f l)$ AlbCre ${ }^{-}$mice, $n=15 ; O B / O B-P P A R \gamma(f l / f I)$ $\mathrm{AlbCre}^{+}, n=16 ; o b / o b-\mathrm{PPAR} \gamma(f l / f l) \mathrm{AlbCre}^{-}$, $n=16$; and $o b / o b-\operatorname{PPAR} \gamma(f l / f l) A l b C r e^{+}, n=11$. (b and c) Glucose tolerance test. 10-week-old (b) and 6-week-old (c) mice were injected with glucose $(2 \mathrm{mg} / \mathrm{g})$. For 10-week-old mice, $O B / O B-P P A R \gamma(f l / f l) A l b C r e^{-}$mice, $n=8$; $O B / O B-P P A R \gamma(f l / f l) A l b C r e^{+}, n=9 ; o b / o b-$ PPAR $\gamma(f l / f l) A l b C r e^{-}, n=19$; and $o b / o b$-PPAR $\gamma$ (fl/fl)AlbCre ${ }^{+}, n=15$. For 6-week-old mice, $o b / o b$-PPAR $\gamma(f l / f l) A l b C r e^{-}, n=9$; and $o b / o b$ PPAR $\gamma(f l / f l) A l b C r e^{+}, n=8$. (d and e) Effect of rosiglitazone on glucose and insulin levels. Both of these measurements were performed using the same samples. For 20-week-old mice, $o b / o b$-PPAR $\gamma(f l / f l) A l b C r e^{-}, \quad n=13 ; o b / o b-$ PPAR $\gamma(f l / f l) A l b C r e^{+}, n=8$. For 7-week-old mice, ob/ob-PPAR $\gamma(f l / f l) A l b C r e^{-}, n=11 ; o b / o b$ PPAR $\gamma(f l / f l) A l b C r e^{+}, n=6$. (f-i) Hyperinsulinemic-euglycemic clamp. Measurements of $(\mathbf{f})$ whole-body glucose uptake ( $\mathbf{g}$ ) suppression of basal endogenous glucose production (EGP) (h) white adipose glucose uptake, and (i) muscle glucose uptake. Male 5-week-old mice were used in this experiment. For $o b / o b$-PPAR $\gamma(f l / f l)$ AlbCre ${ }^{-}$mice, $n=4 ; o b / o b-P P A R \gamma(f l / f l) A l b C r e^{+}$, $n=6$. All data are mean $\pm \mathrm{SE} .{ }^{*} P<0.05$, Cre ${ }^{-}$ vs. $\mathrm{Cre}^{+}$mice. $(\mathbf{j}-\mathbf{o})$ Effect of rosiglitazone on glucose levels ( $\mathbf{j}$ and $\mathbf{I})$, glucose tolerance $(\mathbf{k})$, insulin levels (m), FFA (n), and TG (o) in ob/ob mice. The legend to Figure 21 describes the conditions for rosiglitazone treatment in the glucose analysis studies $(\mathbf{j})$. For rosiglitazone-treated mice: $o b / o b$-PPAR $\gamma(f l / f l) A l b C r e^{-}, n=11$; $o b / o b$-PPAR $\gamma(f l / f l) A l b C r e^{+}, n=4$. For control mice: $o b / o b$-PPAR $\gamma(f l / f l) A l b C r e^{-}, n=10 ; o b / o b$ $\operatorname{PPAR} \gamma(f l / f l) \mathrm{AlbCre}^{+}, n=4$. All data are mean \pm SE. ${ }^{*} P<0.05,{ }^{*} P<0.01,{ }^{*}{ }^{*} P<0.001$, rosiglitazone-treated vs. control $\mathrm{Cre}^{-}$mice. ${ }^{\dagger} P<0.05$, ${ }^{\dagger \dagger} P<0.01$, ${ }^{\dagger \dagger} P<0.001$, rosiglitazone-treated vs. control $\mathrm{Cre}^{+}$mice. Rosi, rosiglitazone; Cont, control. all known PPAR $\alpha$ target genes (41). These results indicate that although expression of PPAR $\gamma$ in liver is lower than PPAR $\alpha$, it appears that residual PPAR $\gamma$ is capable of mimicking PPAR $\alpha$ function with activation by potent agonist.

PPAR $\gamma$ is known to activate the expression of LXR $\alpha$ in macrophages $(4,5)$. Furthermore, SREBP1c expression is markedly increased in an LXR-dependent manner $(42,43)$. Therefore, Northern blotting was performed to elucidate whether LXR $\alpha$, SREBP1, and PPAR $\alpha$ are mediating some of the PPAR $\gamma$-dependent phenotypes in liver. However, no difference in expression between $o b / o b$-PPAR $\gamma(f l / f l) \mathrm{AlbCre}^{-}$and $\mathrm{Cre}^{+}$mice was observed for the SREBP $1, L X R \alpha$, or PPAR $\alpha$ genes, suggesting that, at least at the mRNA level, these genes are not associated with the phenotypes obtained with the PPAR $\gamma$ liver-null $o b / o b$ mice. Interestingly, SREBP1 mRNA in rosiglitazone-treated $o b / o b$ mice were elevated in a PPAR $\gamma$-independent manner. These results raise the possibility that rosiglitazone modulates the expression of these transcriptional factors through non-PPAR $\gamma$-dependent pathways. 
Elevation of serum TG and FFA levels in hepatic PPAR $\gamma$-deficient mice. Levels of TG and FFA in $o b / o b$ $\operatorname{PPAR} \gamma(f l / f l) \mathrm{AlbCre}^{+}$mice were significantly higher than in $o b / o b$-PPAR $\gamma(f l / f l)$ AlbCre $e^{-}$mice. High levels of serum TG and FFA appear to be derived from elevated VLDL in blood. In addition, $o b / o b$-PPAR $\gamma(f l / f l) \mathrm{AlbCre}^{+}$mice have a tendency to accumulate not only VLDL but also chylomicrons as exogenous TG-rich lipoproteins.

The mechanism of elevated FFA and TG levels in hepatic PPAR $\gamma$-null $o b / o b$ mice remains to be defined. We believe the mechanism may be mediated by hormone-sensitive lipase in white adipose that results in decreased insulin sensitivity in hepatic PPAR $\gamma$-null $o b / o b$ mice. This severe insulin resistance would prevent the antilipolysis effect of insulin and may cause lipolysis in adipose, although high levels of TG are not accounted for by this mechanism.

In addition, VLDL and chylomicron accumulation in blood suggests that the hepatic PPAR $\gamma$-null $o b / o b$ mice have an impairment in TG-rich lipoprotein clearance. These results raise the possibility that the deficiency of hepatic PPAR $\gamma$ indirectly causes the decrease of lipoprotein lipase activity, which has a crucial role in the catabolism of TG-rich lipoproteins. However, no significant differences in lipoprotein lipase activity were observed, although hepatic lipase activity was significantly increased in $o b / o b$-PPAR $\gamma(f l / f l) \mathrm{AlbCre}^{+}$mice. Hepatic lipase elevation in $o b / o b$-PPAR $\gamma(f l / f l) \mathrm{AlbCre}^{+}$mice does not appear to significantly affect TG and FFA levels because hepatic lipase preferentially hydrolyzes TG from HDL and IDL/LDL, and not from VLDL (44). Even if hepatic lipase contributes to the catabolism of TG-rich lipoproteins, the increased activity will generate an opposite situation from the high TG level observed in $o b / o b$-PPAR $\gamma(f l / f l) \mathrm{AlbCre}^{+}$mice. Therefore, the low TG clearance rate may result from impaired uptake. We could not observe a difference in expression of LDL receptor, scavenger receptor class B type I, or apoE between $o b / o b$-PPAR $\gamma(f l / f l) A l b C r e^{-}$and $o b / o b$ $\operatorname{PPAR} \gamma(f l / f l) A l b C r e^{+}$liver. However, we cannot rule out other factors that mediate the uptake of lipoproteins and their remnants, including TG. Further studies are needed to determine the mechanism for elevation of TG and FFA in $o b / o b$-PPAR $\gamma(f l / f l) \mathrm{AlbCre}^{+}$mice.

In lep ${ }^{o b / o b} \times S r e b p 1^{-/-}$mice, plasma cholesterol levels were decreased (38), while the plasma cholesterol levels in $o b / o b$-PPAR $\gamma$-null mice were increased compared with $o b / o b$ mice. It is known that SREBP1 positively regulates expression of the LDL receptor through sterol regulatory element-1 in the promoter region (45). However, SREBP1-null mice had decreased plasma cholesterol levels (46) like SREBP1-deficient $o b / o b$ mice. It is thought that SREBP2, which is increased by a deficiency in SREBP1, compensates for the loss of SREBP1 (46). Therefore, SREBP1-deficient mice achieve decreased cholesterol levels by mediating uptake through increased LDL receptor. The same mechanism could account for the phenotype of $l e p^{o b / o b} \times$ Srebp $1^{-/-}$ mice. Contrary to the SREBP1 study, we did not observe a difference in expression of LDL receptor mRNA between $o b / o b$-PPAR $\gamma(f l / f l) \mathrm{AlbCre}^{-}$and $o b / o b$ PPAR $\gamma(f l / f l) A l b C r e^{+}$mice (data not shown).

Deficiency of liver-specific PPAR $\gamma$ improves liver insulin sensitivity but further aggravates hyperglycemia and muscle and fat insulin resistance. The $o b / o b$ mouse is a valuable model for insulin resistance and type 2 diabetes. The relationship between PPAR $\gamma$ and insulin sensitivity is highly controversial $(47,48)$. In our studies, the deficiency of hepatic PPAR $\gamma$ aggravated the hyperglycemia and glucose intolerance in $o b / o b$ mice. This result was surprising, since reduction in hepatic steatosis would be expected to increase liver insulin sensitivity and therefore improve glycemic control. The clamp study revealed that while liver insulin sensitivity in PPAR $\gamma$-deficient $o b / o b$ mice was relatively improved, fat and muscle insulin resistance was, to the contrary, further aggravated.

The mechanism of how hepatic PPAR $\gamma$ influences glucose clearance or insulin resistance is likely complex. One possible factor is high lipids in the blood. In agreement with a role for systemic FFA in the development of type 2 diabetes, it was shown that elevation of plasma FFA induces peripheral insulin resistance in humans and in rodent models within a few hours (49, 50). In addition, it was shown that FFA can have positive or negative effects on insulin secretion, depending on the experimental conditions used $(51,52)$. Thus, FFA might have a direct impact on glucose homeostasis via systemic insulin sensitivity and possibly through effects on insulin secretion.

The basal endogenous glucose production in PPAR $\gamma$ null $o b / o b$ mice was significantly higher than in $o b / o b$ mice $(92.75 \pm 2.78 \mu \mathrm{mol} / \mathrm{kg} / \mathrm{min}$ vs. $128.67 \pm 6.36$ $\mu \mathrm{mol} / \mathrm{kg} / \mathrm{min}, P<0.01)$. However, endogenous glucose production does not always correlate well with liver insulin sensitivity as measured under standardized clamp conditions with comparable insulinemia and glycemia. PPAR $\gamma$ deletion "protects" liver against lipid overload, thus blunting the negative effects of circulating or hepatic lipids on liver insulin sensitivity. This leads to improvement in liver insulin sensitivity, i.e., relatively greater suppression of endogenous glucose production under clamp (hyperinsulinemic) conditions. This is in agreement with other studies showing that tissue lipid levels (53), rather than circulating lipid levels, is the principal determinant of tissue insulin sensitivity.

It was demonstrated that $P P A R \gamma^{\dagger /-}$ mice were protected from the development of high fat diet-induced insulin resistance (7). After 15 weeks on a high-fat diet, blood glucose levels tended to be lower in $P P A R \gamma^{+-}$mice, and in a glucose tolerance test, the response of $P P A R \gamma^{+/-}$mice was lower than in the wild type. In the present report, deficiency of liver-specific PPAR $\gamma$ showed an opposite phenotype with respect to glucose metabolism. However, it should be noted that the mice generated in the present study and by earlier work (7) differ in at least two points. The $o b / o b$ $\operatorname{PPAR} \gamma(f l / f l) \mathrm{AlbCre}^{+}$mice are deficient in liver-specific 
PPAR $\gamma$ and do not have functional leptin. Therefore, the data obtained with the two mouse lines are not directly comparable.

The mechanism of how hepatic PPAR $\gamma$ is induced in $o b / o b$ mouse liver remains elusive. It is known that the expression of hepatic PPAR $\gamma$ is increased in some obese and diabetic model mice (17-21). These mice have phenotypes common to diabetic syndromes. This raises the possibility that longer periods of exposure to high insulin or glucose induces PPAR $\gamma$ in liver. In vitro studies have demonstrated that insulin induces PPAR $\gamma$ expression (54). Furthermore, a recent report revealed that PPAR $\gamma$ is not expressed in fatty livers induced by starvation or by choline-deficient diets (55). These observations clearly demonstrate that hepatic fatty change itself is not enough to induce PPAR $\gamma$. Further experimentation is needed in order to determine the mechanism by which PPAR $\gamma$ is activated in $o b / o b$ mouse liver.

In summary, liver-specific disruption of PPAR $\gamma$ in diabetic mice dramatically decreased hepatic TG and systemically aggravated insulin resistance. However, the effect of rosiglitazone on glucose levels did not depend on hepatic PPAR $\gamma$. Results in this report and other reports (18) suggest that adipose tissue is required for the antihyperglycemic effect of rosiglitazone.

\section{Acknowledgments}

We are grateful to Christopher J. Nicol, Taro E. Akiyama, Linda G. Byrd, and Shioko Kimura for their helpful suggestions. K. Matsusue was supported by a postdoctoral fellowship from the Japanese Society for the Promotion of Science.

1. Hihi, A.K., Michalik, L., and Wahli, W. 2002. PPARs: transcriptional effectors of fatty acids and their derivatives. Cell. Mol. Life Sci. 59:790-798.

2. Bocher, V., Pineda-Torra, I., Fruchart, J.C., and Staels, B. 2002. PPARs: transcription factors controlling lipid and lipoprotein metabolism. Ann. N. Y. Acad. Sci. 967:7-18.

3. Rosen, E.D., et al. 2002. C/EBPalpha induces adipogenesis through PPARgamma: a unified pathway. Genes Dev. 16:22-26.

4. Akiyama, T.E., et al. 2002. Conditional disruption of the peroxisome proliferator-activated receptor gamma gene in mice results in lowered expression of ABCA1, ABCG1, and apoE in macrophages and reduced cholesterol efflux. Mol. Cell. Biol. 22:2607-2619.

5. Chawla, A., et al. 2001. A PPAR gamma-LXR-ABCA1 pathway in macrophages is involved in cholesterol efflux and atherogenesis. Mol. Cell. 7:161-171.

6. Barak, Y., et al. 1999. PPAR gamma is required for placental, cardiac, and adipose tissue development. Mol. Cell. 4:585-595.

7. Kubota, N., et al. 1999. PPAR gamma mediates high-fat diet-induced adipocyte hypertrophy and insulin resistance. Mol. Cell. 4:597-609.

8. Rosen, E.D., et al. 1999. PPAR gamma is required for the differentiation of adipose tissue in vivo and in vitro. Mol. Cell. 4:611-617.

9. Chawla, A., Schwarz, E.J., Dimaculangan, D.D., and Lazar, M.A. 1994. Peroxisome proliferator-activated receptor (PPAR) gamma: adipose-predominant expression and induction early in adipocyte differentiation. Endocrinology. 135:798-800.

10. Tontonoz, P., Hu, E., Graves, R.A., Budavari, A.I., and Spiegelman, B.M. 1994. mPPAR gamma 2: tissue-specific regulator of an adipocyte enhancer. Genes Dev. 8:1224-1234.

11. Lefebvre, A.M., et al. 1998. Activation of the peroxisome proliferatoractivated receptor gamma promotes the development of colon tumors in C57BL/6J-APCMin/+ mice. Nat. Med. 4:1053-1057.

12. Saez, E., et al. 1998. Activators of the nuclear receptor PPARgamma enhance colon polyp formation. Nat. Med. 4:1058-1061.

13. Seed, B. 1998. PPARgamma and colorectal carcinoma: conflicts in a nuclear family. Nat. Med. 4:1004-1005.
14. Moore, K.J., Fitzgerald, M.L., and Freeman, M.W. 2001. Peroxisome proliferator-activated receptors in macrophage biology: friend or foe? Curr. Opin. Lipidol. 12:519-527.

15. Fajas, L., et al. 1997. The organization, promoter analysis, and expression of the human PPARgamma gene. J. Biol. Chem. 272:18779-18789.

16. Peters, J.M., Rusyn, I., Rose, M.L., Gonzalez, F.J., and Thurman, R.G. 2000. Peroxisome proliferator-activated receptor alpha is restricted to hepatic parenchymal cells, not Kupffer cells: implications for the mechanism of action of peroxisome proliferators in hepatocarcinogenesis. Carcinogenesis. 21:823-826.

17. Burant, C.F., et al. 1997. Troglitazone action is independent of adipose tissue. J. Clin. Invest. 100:2900-2908.

18. Chao, L., et al. 2000. Adipose tissue is required for the antidiabetic, but not for the hypolipidemic, effect of thiazolidinediones. J. Clin. Invest. 106:1221-1228.

19. Memon, R.A., et al. 2000. Up-regulation of peroxisome proliferator-activated receptors (PPAR-alpha) and PPAR-gamma messenger ribonucleic acid expression in the liver in murine obesity: troglitazone induces expression of PPAR-gamma-responsive adipose tissue-specific genes in the liver of obese diabetic mice. Endocrinology. 141:4021-4031.

20. Rahimian, R., et al. 2001. Hepatic over-expression of peroxisome proliferator activated receptor gamma2 in the ob/ob mouse model of noninsulin dependent diabetes mellitus. Mol. Cell. Biochem. 224:29-37.

21. Bedoucha, M., Atzpodien, E., and Boelsterli, U.A. 2001. Diabetic KKAy mice exhibit increased hepatic PPARgamma1 gene expression and develop hepatic steatosis upon chronic treatment with antidiabetic thiazolidinediones. J. Hepatol. 35:17-23.

22. Yakar, S., et al. 1999. Normal growth and development in the absence of hepatic insulin-like growth factor I. Proc. Natl. Acad. Sci. U. S. A. 96:7324-7329.

23. Hayhurst, G.P., Lee, Y.H., Lambert, G., Ward, J.M., and Gonzalez, F.J. 2001. Hepatocyte nuclear factor 4alpha (nuclear receptor 2A1) is essential for maintenance of hepatic gene expression and lipid homeostasis. Mol. Cell. Biol. 21:1393-1403.

24. Bligh, E.G., and Dyer, W.J. 1959. A rapid method of total lipid extraction and purification. Can. J. Biochem. Physiol. 37:911-917.

25. Iverius, P.H., and Brunzell, J.D. 1985. Human adipose tissue lipoprotein lipase: changes with feeding and relation to postheparin plasma enzyme. Am. J. Physiol. 249:E107-E114.

26. Vaisman, B.L., et al. 2001. ABCA1 overexpression leads to hyperalphalipoproteinemia and increased biliary cholesterol excretion in transgenic mice. J. Clin. Invest. 108:303-309. doi:10.1172/JCI200112517.

27. Haluzik, M., et al. 2002. Adrenalectomy improves diabetes in A-ZIP/F-1 lipoatrophic mice by increasing both liver and muscle insulin sensitivity. Diabetes. 51:2113-2118.

28. Peters, J.M., Rusyn, I., Rose, M.L., Gonzalez, F.J., and Thurman, R.G. 2000. Peroxisome proliferator-activated receptor alpha is restricted to hepatic parenchymal cells, not Kupffer cells: implications for the mechanism of action of peroxisome proliferators in hepatocarcinogenesis. Carcinogenesis. 21:823-826.

29. Postic, C., et al. 1999. Dual roles for glucokinase in glucose homeostasis as determined by liver and pancreatic beta cell-specific gene knockouts using Cre recombinase. J. Biol. Chem. 274:305-315.

30. Davies, G.F., McFie, P.J., Khandelwal, R.L., and Roesler, W.J. 2002. Unique ability of troglitazone to up-regulate peroxisome proliferatoractivated receptor-gamma expression in hepatocytes. J. Pharmacol. Exp. Ther. 300:72-77.

31. Liang, C.P., and Tall, A.R. 2001. Transcriptional profiling reveals global defects in energy metabolism, lipoprotein, and bile acid synthesis and transport with reversal by leptin treatment in ob/ob mouse liver. J. Biol. Chem. 276:49066-49076.

32. Drochmans, P., Wanson, J.C., and Mosselmans, R. 1975. Isolation and subfractionation on ficoll gradients of adult rat hepatocytes. Size, morphology, and biochemical characteristics of cell fractions. J. Cell Biol. 66:1-22.

33. Kishida, K., et al. 2001. Enhancement of the aquaporin adipose gene expression by a peroxisome proliferator-activated receptor gamma. J. Biol. Chem. 276:48572-48579.

34. Shimomura, I., Bashmakov, Y., and Horton, J.D. 1999. Increased levels of nuclear SREBP-1c associated with fatty livers in two mouse models of diabetes mellitus. J. Biol. Chem. 274:30028-30032.

35. Zinman, B. 2001. PPAR gamma agonists in type 2 diabetes: how far have we come in 'preventing the inevitable'? A review of the metabolic effects of rosiglitazone. Diabetes Obes. Metab. 3(Suppl. 1):S34-S43.

36. Lehmann, J.M., et al. 1995. An antidiabetic thiazolidinedione is a high affinity ligand for peroxisome proliferator-activated receptor gamma (PPAR gamma). J. Biol. Chem. 270:12953-12956.

37. Horton, J.D., Goldstein, J.L., and Brown, M.S. 2002. SREBPs: activators of the complete program of cholesterol and fatty acid synthesis in the liver. J. Clin. Invest. 109:1125-1131. doi:10.1172/JCI200215593.

38. Yahagi, N., et al. 2002. Absence of sterol regulatory element-binding protein-1 (SREBP-1) ameliorates fatty livers but not obesity or insulin 
resistance in Lep(ob)/Lep(ob) mice. J. Biol. Chem. 277:19353-19357.

39. Castelein, H., et al. 1994. The peroxisome proliferator activated recepto regulates malic enzyme gene expression. J. Biol. Chem. 269:26754-26758.

40. Miller, C.W., and Ntambi, J.M. 1996. Peroxisome proliferators induce mouse liver stearoyl-CoA desaturase 1 gene expression. Proc. Natl. Acad. Sci.U. S. A. 93:9443-9448.

41. DeLuca, J.G., et al. 2000. Evidence for peroxisome proliferator-activated receptor (PPAR)alpha-independent peroxisome proliferation: effects of PPARgamma/delta-specific agonists in PPARalpha-null mice. Mol. Pharmacol. 58:470-476.

42. Yoshikawa, T., et al. 2001. Identification of liver $X$ receptor-retinoid $X$ receptor as an activator of the sterol regulatory element-binding protein 1c gene promoter. Mol. Cell Biol. 21:2991-3000.

43. Repa, J.J., et al. 2000. Regulation of mouse sterol regulatory elementbinding protein-1c gene (SREBP-1c) by oxysterol receptors, LXRalpha and LXRbeta. Genes Dev. 14:2819-2830.

44. Jansen, H., Verhoeven, A.J., and Sijbrands, E.J. 2002. Hepatic lipase: a proor anti-atherogenic protein? J. Lipid Res. 43:1352-1362.

45. Streicher, R., et al. 1996. SREBP-1 mediates activation of the low density lipoprotein receptor promoter by insulin and insulin-like growth factor-I. J. Biol. Chem. 271:7128-7133.

46. Shimano, H., et al. 1997. Elevated levels of SREBP-2 and cholesterol synthesis in livers of mice homozygous for a targeted disruption of the SREBP-1 gene. J. Clin. Invest. 100:2115-2124.

47. Lebovitz, H.E., and Banerji, M.A. 2001. Insulin resistance and its treat- ment by thiazolidinediones. Recent Prog. Horm. Res. 56:265-294.

48. Picard, F., and Auwerx, J. 2002. PPAR(gamma) and glucose homeostasis. Annu. Rev. Nutr. 22:167-197.

49. Dresner, A., et al. 1999. Effects of free fatty acids on glucose transport and IRS-1-associated phosphatidylinositol 3-kinase activity. J. Clin. Invest. 103:253-259.

50. Roden, M., et al. 1996. Mechanism of free fatty acid-induced insulin resistance in humans. J. Clin. Invest. 97:2859-2865.

51. McGarry, J.D., and Dobbins, R.L. 1999. Fatty acids, lipotoxicity and insulin secretion. Diabetologia. 42:128-138.

52. Sako, Y., and Grill, V.E. 1990. A 48-hour lipid infusion in the rat timedependently inhibits glucose-induced insulin secretion and B cell oxidation through a process likely coupled to fatty acid oxidation. Endocrinology. 127:1580-1589.

53. Hajri, T., Han, X.X., Bonen, A., and Abumrad, N.A. 2002. Defective fatty acid uptake modulates insulin responsiveness and metabolic responses to diet in CD36-null mice. J. Clin. Invest. 109:1381-1389. doi:10.1172/JCI200214596.

54. Rieusset, J., et al. 1999. Insulin acutely regulates the expression of the peroxisome proliferator-activated receptor-gamma in human adipocytes. Diabetes. 48:699-705.

55. Yu, S., et al. 2003. Adipocyte-specific gene expression and adipogenic steatosis in the mouse liver due to peroxisome proliferator-activated receptor gamma1 (PPARgamma1) overexpression. J. Biol. Chem. 278:498-505 